\title{
Perbaikan Sensitivitas Insulin Diabetes Melitus Tipe 2 oleh Media Terkondisi Sel Punca Mesensimal
}

\author{
Bernadia Branitamahisi \\ Universitas Katolik Soegijapranata Semarang \\ email: bernadia@unika.ac.id
}

\begin{abstract}
Type 2 diabetes mellitus is the highest prevalence among diabetes types, but there is no treatment that overcome obstacle in the process of surgery, rejection reactions, and increased complications that occur. The aim of this study was to investigate the insulin sensitivity improvement by Mesenchymal Stem Cell-Conditioned Medium(MSC-CM) through increased IRS-1 tyrosine phosphorylation (IRS$1^{\text {tyr612}}$ ) on the type 2 diabetic rat with and without treatment. This experimental study is purely laboratory Posttest Control Group using male Sprague Dawley rat, 7 weeks old and 150-200gram weight. Rat is divided into 3 research groups, $K(-)$ : normal control; $K(+)$ : diabetic control; $P$ :treatment, type 2 DM rat $+M S C-C M 0,1 \mathrm{ml} / 200 \mathrm{gBW}$ ip. Giving MSC-CM is done every 3 days 10 times. On day 30 after therapy, an IRS-1 $1^{\text {tyr612 }}$ expression analysis was performed with skeletal muscle immunohistochemistry (IHC). Data analysis was performed by Kruskal-Wallis and Independent Sample T-test at 95\% significance. Percentage of positive score of IRS- $1^{\text {tyr612 }}$ expression K(-)(75\%)> $P(62,5 \%)>K(+)(12,5 \%)$. Average expression of IRS- $1^{\text {tyr612 }} P(45,46 \pm 9,15)>K(-)(44,41 \pm 4,61)>$ $K(+)(21,29 \pm 3,49)$ with significant difference of $K(-)-K(+)$ and $P-K(+)$. Giving MSC-CM may increase the expression of IRS-1 $1^{\text {tyr612 }}$ on type 2 diabetic animal model rat.
\end{abstract}

Keywords: MSC-CM, insulin sensitivity, IRS-1 ${ }^{\text {tyr612 }}$, type 2 DM

\begin{abstract}
Abstrak
Diabetes melitus tipe 2 merupakan tipe diabetes dengan prevalensi tertinggi, namun belum ada pengobatan yang dapat mengatasi hambatan dalam proses operasi, reaksi rejeksi, dan banyaknya komplikasi yang terjadi. Penelitian ini bertujuan untuk mengetahui perbaikan sensitivitas insulin oleh Media Terkondisi Sel Punca Mesensimal (MT-SPM) melalui peningkatan fosforilasi tirosin 612 IRS$1\left(\right.$ IRS- $1^{\text {tyr612 }}$ ) pada tikus model DM tipe 2 dengan dan tanpa terapi. Penelitian ini eksperimental murni laboratorium Posttest Control Group menggunakan hewan uji tikus Sprague Dawley jantan usia 7 minggu dan berat badan 150-200gram. Tikus dibagi menjadi 3 kelompok penelitian, yaitu K(-): kontrol normal; $\mathrm{K}(+)$ : kontrol diabetik; P: perlakuan, tikus DM tipe $2+$ MT-SPM 0,1ml/200g bb ip. Pemberian MT-SPM dilakukan setiap 3 hari sebanyak 10 kali. Pada hari ke-30 setelah terapi, dilakukan analisis ekspresi IRS-1 ${ }^{\text {ty612 }}$ dengan IHC otot skelet. Analisis data dilakukan dengan Independent Sample T-test dan Kruskal Wallis pada signifikansi 95\%. Prosentase skor positif ekspresi IRS-1 $1^{\text {tyr612 }} \mathrm{K}(-)(75 \%)>\mathrm{P}(62,5 \%)>\mathrm{K}(+)(12,5 \%)$. Rerata ekspresi IRS-1 ${ }^{\text {tyr612 }} \mathrm{P}(45,46 \pm 9,15)>\mathrm{K}(-$ )$(44,41 \pm 4,61)>\mathrm{K}(+)(21,29 \pm 3,49)$ dengan perbedaan yang bermakna secara statistik pada $\mathrm{K}(-)-\mathrm{K}(+)$ dan P-K(+). Pemberian MTSPM dapat meningkatkan ekspresi IRS-1 $1^{\text {tyr612 }}$ pada tikus model DM tipe 2.
\end{abstract}

Kata kunci: MT-SPM, sensitivitas insulin, IRS-1 ${ }^{\mathrm{tyr} 612}$,DM tipe 2 


\section{PENDAHULUAN}

Diabetes melitus tipe 2 merupakan tipe diabetes dengan prevalensi tertinggi, namun belum ada pengobatan yang dapat mengatasi hambatan dalam proses operasi, reaksi rejeksi, dan banyaknya komplikasi yang terjadi. Sel punca saat ini sedang dikembangkan untuk terapi DM, namun proses diferensiasinya dalam tubuh belum terkontrol dengan maksimal dan dapat membentuk tumor (Tatullo et al. 2015). Sel punca mesensimal yang belum berdiferensiasi tumbuh dalam media terkondisi. Media terkondisi SPM (MTSPM) lebih unggul dibandingkan SPM karena mengandung berbagai metabolit bioaktif yang dapat memicu sel dewasa rusak untuk memperbaiki dirinya dan membangunkan sel dorman, berefek antiinflamasi, imunogenisitas rendah, nontumorigenesis, dan penggunaannya hanya sedikit memicu masalah etika, sehingga potensial sebagai agen pengobatan regeneratif (Laqif 2015; Toda et al. 2007).

Perbaikan sensitivitas insulin pada tikus model DM tipe 2 dapat diketahui dari peningkatan fosforilasi tirosin 612 IRS-1 $\left(I R S-1^{\text {tyr612 }}\right)$. Insulin Receptor Substrate 1 (IRS-1) merupakan salah satu gen marker DM tipe 2 yang berperan dalam insulin signaling pathway.Penelitian ini bertujuan untuk mengetahui perbaikan sensitivitas insulin oleh Media Terkondisi Sel Punca Mesensimal (MT-SPM) melalui peningkatan fosforilasi tirosin 612 IRS-1(IRS-1 $\left.{ }^{\text {tyr612 }}\right)$ pada tikus model DM tipe 2 dengan dan tanpa terapi.

\section{TELAAH LITERATUR DAN PENGEMBANGAN HIPOTESIS}

Diabetes melitus didefinisikan sebagai kelompok penyakit metabolik yang dicirikan oleh hiperglikemia kronis yang dihasilkan dari gangguan sekresi insulin, aktivitas insulin, atau keduanya (Ferdous et al. 2016). Diabetes melitus tipe 2 merupakan tipe DM yang disebabkan oleh resistensi insulin, kemudian lebih lanjut gangguan sekresi insulin akibat dekompensasi sel $\beta$ pankreas. Diabetes melitus tipe 2 paling sering terjadi dibandingkan tipe diabetes yang lain (IDF 2006). Telah banyak dilakukan terapi pada penderita penyakit ini, tetapi masih memiliki banyak kelemahan. Penderita DM tipe 2 sering kali mengalami peningkatan risiko pengembangan komplikasi makrovaskular dan mikrovaskular, sehingga diperlukan pengobatan yang dapat memperbaiki kondisi penderita DM tipe 2 sekaligus mengurangi resiko komplikasi maupun komorbiditas (ADA 2017).

Pengobatan DM tipe 2 yang sedang dikembangkan untuk menanggulangi resiko komplikasi maupun komorbiditas adalah dengan menggunakan sel punca, namun 
proses diferensiasinya dalam tubuh belum terkontrol dengan maksimal dan dapat membentuk tumor, sehingga perlu dicari terapi lain yang lebih aman (Tatullo et al. 2015). Media terkondisi SPM berpotensi dikembangkan sebagai agen pengobatan regeneratif karena menurut Tatullo et al.(2015) kemampuan biomaterial, growth factor maupun sel punca dalam meningkatkan, memulihkan atau mengganti fungsi biologis dari organ dan jaringan merupakan sifat agen pengobatan regeneratif.

Kandungan metabolit bioaktif pada MT-SPM potensial dikembangkan menjadi agen pengobatan regeneratif dan ko-terapi DM tipe 2. Dosis MTSPM yang digunakan dalam penelitian ini adalah $0,1 \mathrm{ml} / 200 \mathrm{gBB}$ berdasarkan uji pendahuluan. Pada uji pendahuluan, tikus dengan terapi MTSPM dosis $0,1 \mathrm{ml} / 200 \mathrm{gBB}$ mengalami penurunan Kadar Glukosa Darah Puasa (KGDP) lebih cepat dan memiliki profil histopatologis sel $\beta$ pankreas lebih baik dibandingkan kelompok terapi MTSPM dosis 0,3ml/200gBB dan kelompok kontrol DM. Perbaikan resistensi/sensitivitas insulin pada tikus model DM tipe 2 dapat diketahui dari perubahan ekspresi gen marker DM tipe 2.

Gen yang berperan dalam DM tipe 2 sudah banyak ditemukan, termasuk IRS-1. Perubahan ekspresi gen IRS-1 menyebabkan resistensi insulin terutama pada terganggunya transduksi signal insulin terstimulasi, karena protein IRS-1 berperan sebagai substrat dari insulin reseptor tirosin kinase. Keterlibatan IRS-1 dalam insulin signaling pathway mencakup serangkaian proses yang kompleks, yaitu diawali pengikatan insulin pada sub unit $\alpha$ reseptor insulin, dan diikuti reaksi autofosforilasi subunit $\beta$ pada target protein (Sari 2007).

Target protein yang terfosforilasi oleh aktivasi IRS-1 diantaranya adalah tirosin dan serin/treonin. Tirosin dan serin/treonin berperan dalam umpan balik positif maupun umpan balik negatif terhadap insulin (Boucher et al. 2014). Cascade sinyal tirosin terfosforilasi Insulin Receptor Substrate 1 (IRS-1 ${ }^{\text {tyr612 })}$ akan menginduksi pengambilan glukosa ke dalam sel oleh GLUT-4. Di sisi lain, fosforilasi serin dan treonin pada protein reseptor atau IRS terlibat dalam penurunan sinyal insulin, dan lebih lanjut menyebabkan resistensi insulin (Boucher et al. 2014). Komponen growth factor dan sitokin dalam MT-SPM seperti IGF, FGF, dan EGF diharapkan dapat memperbaiki resistensi insulin pada penderita DM tipe 2, terutama dengan meningkatkan ekspresi gen IRS-1 ${ }^{\text {tyr612 }}$ melalui jalur pensinyalan insulin yang juga melibatkan jalur MAPK dan PI3K. 
Berdasarkan pada informasi yang telah didapatkan dari literatur-literatur sebelumnya, maka dapat disusun hipotesis berupa:

$H_{1}$ : Ekspresi tirosin 612 terfosforilasi Insulin Receptor Substrate 1 (IRS$1^{\text {tyr612 }}$ ) lebih tinggi pada tikus model DM tipe 2 dengan terapi dibanding tanpa terapi MT-SPM sehingga memicu perbaikan sensitivitas insulin.

\section{METODE PENELITIAN}

Penelitian ini dilakukan pada bulan Januari - Juli 2017 di laboratorium PAU Pangan dan Gizi UGM, Laboratorium Patologi Anatomi Fakultas Kedokteran UGM, Laboratorium Patologi Fakultas Kedokteran Hewan UGM dan Laboratorium Patologi Anatomi Rumah Sakit Sardjito. Sertifikat ethical clearance untuk penelitian pada hewan coba diterbitkan oleh LPPT 1 UGM. Desain penelitian ini adalah eksperimental murni laboratorium Posttest Control Group menggunakan hewan uji tikus Sprague Dawley jantan usia 7 minggu dan berat badan 150-200gram. Tikus dibagi menjadi 3 kelompok penelitian, yaitu K(-): kontrol normal, 9 tikus normal; $\mathrm{K}(+)$ : kontrol diabetik, 9 tikus DM tipe 2 (injeksi 60mg/kgBB + NA 120mg/kgBB ip) tanpa terapi MT-SPM; P: perlakuan, 9 tikus DM tipe $2+$ MT-SPM 0,1ml/200g bb ip. Pemberian MT-SPM dilakukan setiap 3 hari sebanyak 10 kali. Tikus dinyatakan DM tipe
2 jika kadar glukosa darah puasanya 238mg/dL.

Pengambilan sampel jaringan otot skelet dilakukan saat tikus sudah dieuthanasia. Anestesi dilakukan dengan menyuntikan ketamine 40-100mg/kg IP + xylazine $5-13 \mathrm{mg} / \mathrm{kg}$ IP dalam syringe yang sama untuk mendapatkan durasi anestesi 6080 menit (IACUC UIOWA 2016). Euthanasia tikus dilakukan dengan cervical dislocation di bawah pengaruh obat anestesi (AVMA 2013).

Parameter yang digunakan untuk menguji pengaruh MTSPM terhadap perbaikan resistensi/sensitivitas insulin pada tikus model DM tipe 2 adalah ekspresi IRS$1^{\text {tyr612 }}$. Pada hari ke-30 setelah terapi, dilakukan analisis ekspresi IRS-1 $1^{\text {tyr612 }}$ dengan immunohistochemistry (IHC) otot skelet menggunakan antibodi IRS1(Tyr612) dan kit deteksi Starr Trek Universal HRP Detection System. Setiap pengamatan didokumentasikan dengan perbesaran 100x, 400x, dan 1000x pada tiga lapang pandang setiap sampel. Foto hasil imunohistokimia dianalisis secara kuantitatif menggunakan program ImageJ dengan plugin IHC profiler (Varghese et al. 2014). Skor hasil analisis IHC Profiler digunakan untuk dasar analisis statistik. Analisis data dilakukan dengan Independent Sample T-test dan Kruskal Wallis pada signifikansi 95\%. 


\section{HASIL PENELITIAN DAN \\ PEMBAHASAN}

\section{Pembuatan Hewan Model DM Tipe 2}

Perbaikan sensitivitas insulin diabetes melitus tipe 2 oleh media terkondisi sel punca mesensimal ini diawali dengan tahap pembuatan hewan model. Pada penelitian ini, metode injeksi 60mg/kgBB STZ dan NA 120mg/kgBB ip berhasil membuat tikus SD mengalami DM tipe 2 pada hari ke-5 setelah induksi DM (Gambar 1). Metode induksi DM tipe 2 dengan injeksi STZ-NA digunakan karena lebih merepresentasikan DM tipe 2 seperti yang terjadi pada manusia, terutama untuk menguji potensi efek antidiabetik suatu bahan (Ghasemi et al. 2014). Metode ini mentarget pada fungsi sel $\beta$ pankreas, karena STZ digunakan untuk memicu kematian sel $\beta$ baik secara nekrosis maupun apoptosis, sedangkan NA digunakan untuk melindungi sel $\beta$ dari mekanisme perusakan STZ.

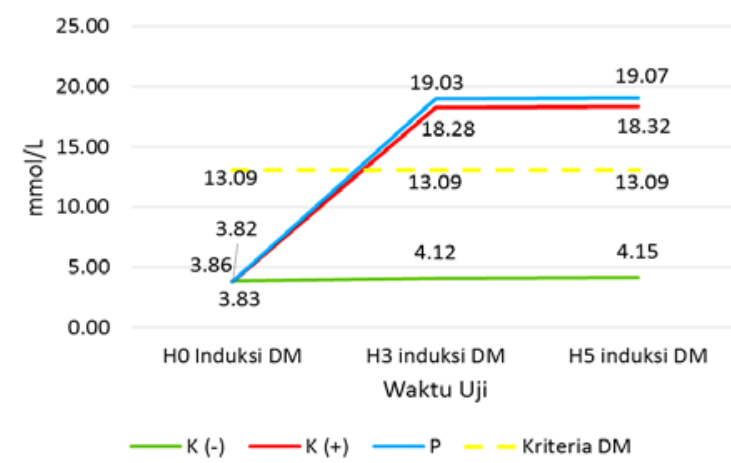

Gambar 1

Perubahan Rerata KGDP selama Pembuatan Hewan Model DM Tipe 2

\section{Pengaruh MTSPM terhadap Ekspresi IRS-1 ${ }^{\text {tyr612 }}$}

\section{Peran MTSPM terhadap Ekspresi IRS-} $1^{\text {tyr612 }}$ Secara Kualitatif

Peningkatan sensitivitas insulin pada tikus model DM tipe 2 secara khusus dapat diketahui berdasarkan perubahan ekspresi IRS-1 ${ }^{\text {tyr612 }}$, karena gen ini berperan penting dalam jalur pensinyalan insulin. Fosforilasi tirosin pada IRS-1 akan meningkatkan sensitivitas insulin, sedangkan fosforilasi serin/treonin akan meningkatkan resistensi insulin. Data hasil analisis ekspresi IRS$1^{\text {tyr612 }}$ menggunakan Image J - IHC Profiler pada preparat otot skelet (Gambar 2-4) kemudian dianalisis secara statistik. Tirosin 612 terfosforilasi IRS-1 dapat diamati secara visual berdasarkan warna kecoklatan yang terlihat di sitoplasma dekat membran sel otot skelet. Letak ekspresi IRS-1 $1^{\text {tyr612 }}$ berada di sitoplasma dekat membran karena IRS merupakan substrat utama reseptor insulin di membran, dan merupakan hulu dari insulin signaling pathway. Pada preparat otot skelet kelompok K(-) (kontrol normal), terdapat serat otot melintang/transversal ( $\mathrm{T}$ ) dan membujur/longitudinal (L) (Gambar 2). Ekspresi IRS-1 ${ }^{\text {tyr612 }}$ pada kelompok normal terlihat merata di hampir seluruh sitoplasma dekat membran sel otot, sehingga batas antar sel terlihat jelas. Hal ini menunjukkan tingginya fosforilasi tirosin 612 IRS-1 pada kelompok normal. 


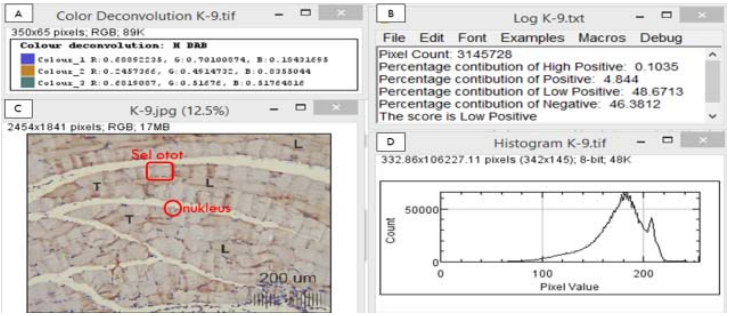

Gambar 2

Gambaran Hasil Analisis Preparat IHC IRS$1^{\text {tyr612 }}$ Otot Skelet K(-) (Kontrol Normal) dengan Image J - IHC Profiler. A. Colour Deconvolution(Piksel Pemisahan Warna Kromogen dan Latar Belakang). B. Hasil Prosentase Kontibusi dan Skor Akhir Ekspresi Low Positive. C. Foto yang Dianalisis

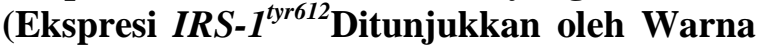
Kecoklatan di Sitoplasma Dekat Membran, Inti Sel di Tepi Sel, Tampak Serat Otot Melintang dan Membujur). D. Histogram Ekspresi Gen Berdasarkan Jumlah dan Nilai Piksel.

Pada foto preparat otot skelet kelompok $\mathrm{K}(+)$ (kontrol diabetes) ini, hanya terdapat serat otot melintang/transversal (T) (Gambar 3). Ekspresi IRS-1 $1^{\text {tyr612 }}$ pada kelompok kontrol diabetes terlihat tidak merata di hampir seluruh sitoplasma dekat membran sel otot, sehingga batas antar sel tidak terlihat dengan jelas. Hal ini dapat terjadi akibat menurunnya fosforilasi tirosin 612 IRS-1 oleh induksi STZ-NA.

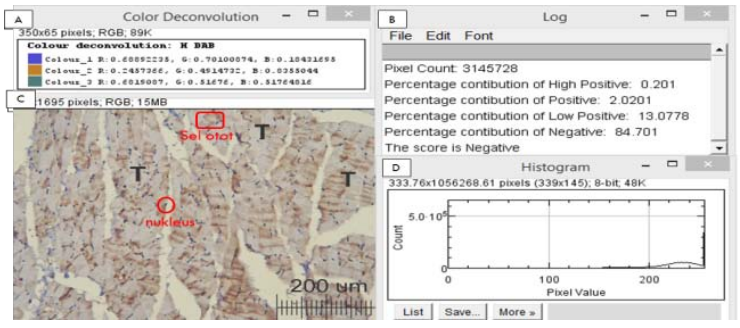

Gambar 3

Gambaran Hasil Analisis Preparat IHC IRS$1^{\text {tyr612 }}$ Otot Skelet $\mathrm{K}(+)$ (Kontrol Diabetes) dengan Image $J$ - IHC Profiler. A. Colour Deconvolution(Piksel Pemisahan Warna Kromogen dan Latar Belakang). B. Hasil
Prosentase Kontibusi dan Skor Akhir Ekspresi Negatif. C. Foto yang Dianalisis (Ekspresi IRS-1 ${ }^{\text {tyr612 Ditunjukkan dengan }}$ Warna Kecoklatan di Sitoplasma Dekat Membran, Inti Sel Berada di Tepi Sel, Tampak Serat Otot Melintang). D. Histogram Ekspresi Gen Berdasarkan Jumlah dan Nilai Piksel.

Pada foto preparat otot skelet kelompok P (perlakuan) hanya terdapat serat otot melintang/transversal (T) (Gambar 4). Ekspresi IRS-1 $1^{\text {tyr612 }}$ pada kelompok perlakuan terlihat tipis merata di hampir seluruh sitoplasma dekat membran sel otot, sehingga batas antar sel terlihat namun tipis. Hal ini dapat terjadi akibat meningkatnya fosforilasi tirosin 612 IRS-1 oleh terapi MTSPM.

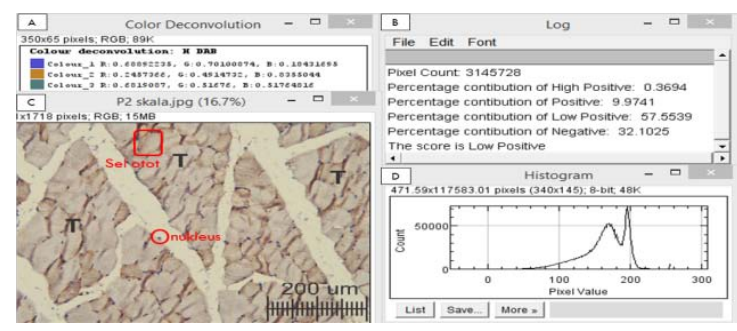

Gambar 4

Gambaran Hasil Analisis Preparat IHC IRS$1^{\text {tyr612 }}$ Otot Skelet $P$ (Perlakuan) dengan Image J - IHC Profiler. A. Colour Deconvolution (Piksel Pemisahan Warna Kromogen dan Latar Belakang). B. Hasil Prosentase Kontibusi dan Skor Akhir Ekspresi Low Negative. C. Foto yang Dianalisis (Ekspresi IRS-1 ${ }^{\text {tyr612 }}$ Ditunjukkan dengan Warna Kecoklatan di Sitoplasma Dekat Membran, Inti Sel Berada di Tepi Sel, Tampak Serat Otot Melintang). D. Histogram Ekspresi Gen Berdasarkan Jumlah dan Nilai Piksel.

\section{Peran MTSPM terhadap Ekspresi IRS-} $1^{\text {tyr612 }}$ Secara Kuantitatif 
Berdasarkan hasil analisis IHC dengan Image J - IHC Profiler, prosentase skor positif ekspresi IRS-1 $1^{\text {tyr612 }}$ tertinggi dimiliki oleh kelompok kontrol negatif (75\%), diikuti oleh kelompok perlakuan (62,5\%), dan terendah dimiliki oleh kelompok kontrol positif (12,5\%) (Gambar 5). Prosentase skor positif ekspresi IRS-1 ${ }^{\text {tyr612 }}$ pada kelompok perlakuan mendekati skor kontrol negatif dan jauh di atas skor kontrol positif. Hal ini menunjukkan bahwa pemberian 0,1ml/200gBB MTSPM memicu peningkatan fosforilasi tirosin 612 IRS-1.

Pada penelitian ini, kelompok perlakuan memiliki rerata ekspresi IRS$1^{\text {tyr612 }}$ tertinggi $(45,46 \pm 9,15)$, diikuti oleh kelompok kontrol negatif $(44,41 \pm 4,61)$, dan paling rendah kelompok kontrol positif $(21,29 \pm 3,49) \quad$ (Gambar 5). Perbedaan peringkat hasil pada perhitungan prosentase skor positif ekspresi IRS-1 $1^{\text {tyr612 }}$ dan rerata ekspresi IRS-1 $1^{\text {tyr612 }}$ ini disebabkan oleh adanya komputerisasi algoritma untuk penentuan skor akhir pada prosentase High Positive, Positive, dan Low Positive IHC Profiler (Gambar 2-4). Selain itu, uji IHC memiliki beberapa faktor subyektivitas, yaitu pada peneliti, reagen (kualitas dan lama simpan), serta sampel itu sendiri, misal pembuatannya baik atau tidak. Kelebihan IHC adalah sangat baik digunakan untuk analisis fosforilasi maupun translokasi protein sebagai bentuk ekspresi dan aktivitas gen, dibandingkan dengan qRT-PCR yang hanya dapat mengukur ekspresi gen total.

Berdasarkan analisis statistik Independent Sample T-test, kelompok kontrol negatif dan positif memliki perbedaan rerata prosentase ekspresi IRS$1^{\text {tyr612 }}$ yang bermakna (Gambar 5). Hal ini menunjukkan bahwa kelompok kontrol positif berhasil menjadi DM dan mengalami gangguan ekspresi IRS-1 $1^{\text {tyr612 }}$. Kelompok kontrol negatif dan perlakuan memiliki perbedaan rerata prosentase ekspresi IRS$1^{\text {tyr612 }}$ yang tidak bermakna, sehingga dapat dikatakan bahwa ekspresi IRS-1 $1^{\text {tyr612 }}$ kelompok perlakuan mirip kelompok kontrol negatif $(p=0,920)$, atau dengan kata lain kelompok perlakuan mengalami perbaikan ekspresi IRS-1 ${ }^{\text {tyr612 }}$ hingga normal.

$$
\text { Pemberian MT-SPM dosis 0,1 }
$$
$\mathrm{ml} / 200 \mathrm{~g}$ BB dapat meningkatkan ekspresi IRS- $1^{\text {tyr612 }}$ pada tikus model DM tipe 2 dengan perbedaan yang bermakna dibandingkan kelompok kontrol positif $(\mathrm{p}=0,027)$. Peningkatan ekspresi IRS-1 $1^{\text {tyr612 }}$ ini berhubungan dengan peran komponen growth factor dalam MTSPM yang dapat mengatur lingkungan mikro lokal pada jaringan rusak, menghambat apoptosis sel, memperbaiki sistem pertahanan imun, serta memicu regenerasi dan revaskularisasi jaringan. Growth factor IGF-1, EGF, dan FGF dapat meningkatkan ekspresi IRS$1^{\text {tyr612 }}$ melalui tyrosine kinase signaling 
pathway, terutama PI3K pathway (McGonnell et al. 2012; Anner'en 2008).

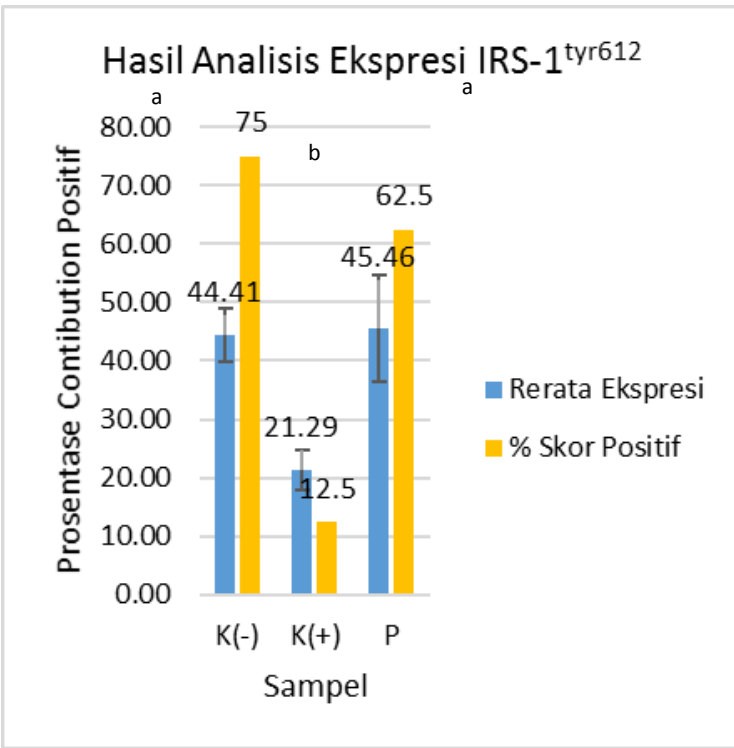

\section{Gambar 5}

Pengaruh Media Terkondisi Sel Punca Mesensimal (MTSPM) terhadap Rerata Prosentase Fosforilasi Tirosin 612 IRS-1Tikus Model Diabetes Melitus Tipe 2. K(-) adalah Kelompok Tikus Non-Diabetes. K (+) adalah Kelompok Tikus Diabetes. $P$ adalah Kelompok Tikus Diabetes dengan Pemberian 0,1ml/200gbb MTSPM. Huruf Berbeda Menunjukkan Hasil yang Berbeda Bermakna, Huruf yang Sama Menunjukkan Perbedaan Tidak Bermakna $(\mathbf{P}>0,05)$.

Berbagai macam komponen MT-SPM memberikan dampak yang beragam pada perubahan kondisi molekular DM tipe 2. Growth factor berupa IGF-1 dan EGF dapat meningkatkan fosforilasi tirosin IRS-1 dan menghambat fosforilasi serin/treonin IRS-1, sedangkan FGF dapat meningkatkan ekspresi gen IRS-1. Beberapa sitokin seperti VEGF, EGF, IGF-1, TGF- $\beta$, AngII, dan IL-7 dapat menghambat fosforilasi tirosin IRS-1 dengan memicu fosforilasi serin/treonin pada IRS-1 atau IR. Degradasi dan disosiasi IRS-1 dapat dipicu oleh aktivitas IL-12, LIF, dan AngII. Sitokin GSTP-1 dapat menghambat kerusakan sel $\beta$ dan protein IRS dengan cara mengikat radikal bebas. Aktivin-B dapat memicu ekspresi gen pensintesis insulin (INS). Kemampuan berbagai sitokin di dalam MT-SPM dalam memulihkan sensitivitas insulin, memicu proliferasi dan diferensiasi sel $\beta$ pankreas, dan meningkatkan pengambilan glukosa darah membuktikan bahwa MT-SPM dapat digunakan sebagai agen pengobatan regeneratif. Kemampuan MT-SPM dalam memulihkan sensitivitas insulin dibuktikan dengan peningkatan fosforilasi tirosin 612 IRS-1 pada tikus model diabetes melitus tipe 2 kelompok perlakuan.

\section{SIMPULAN}

Berdasarkan hasil penelitian yang telah diperoleh dapat disimpulkan bahwa pemberian MTSPMdapat memperbaiki sensitivitas insulin melalui peningkatan ekspresi IRS-1 ${ }^{\text {tyr612 }}$ pada tikus model diabetes melitus tipe 2 dengan perbedaan yang bermakna dibandingkan tanpa pemberian MTSPM.

Saran yang dapat diberikan adalah perlu dilakukan penelitian pengaruh MTSPM terhadap ekspresi IRS-1 $1^{\text {tyr612 }}$ pada tikus model DM tipe 2 dengan injeksi STZNA dan pakan tinggi lemak untuk 
menggambarkan perbaikan sensitivitas insulin dengan lebih baik. Selain itu perlu dilakukan pemisahan komponen MTSPM yang meningkatkan dan menghambat fosforilasi tirosin 612 IRS-1 agar hasil terapi lebih maksimal dan spesifik dalam memperbaiki sensitivitas insulin.

\section{DAFTAR PUSTAKA}

American Diabetes Association.(2017).

Standards of Medical Care in Diabetes.

Diabetes Care, 38(1), S1-S93

Anner'en, C.(2008). Tyrosine Kinase

Signalling in Embryonic Stem Cells.Clin. Sci., 115, 43-55. doi:10.1042/CS20070388

AVMA.(2013). AVMA Guidelines for the Euthanasia of Animals: 2013 Edition. Schaumburg: American Veterinary Medical Association

Boucher, J., Kleinridders, A., Kahn, C.R.(2014).Insulin Receptor Signaling in Normal and Insulin-Resistant States. Cold Spring Harb Perspect Biol, 6(a009191), 1-25, doi:10.1101/cshperspect.a009191
Ferdous, J., Ahmed, S., Laila, R., Islam, M.T., Rahaman, M.F., Snigdha, K.R., Sarkar, S., Khan, A.S., Sarkar, A.K.(2016).Determination of Insulin Secretory Defect and Insulin Sensitivity in Type 2 Diabetic Subjects in Bangladesh. Mymensingh Med J., 25(1), 109-118

Ghasemi, A., Khalifi, S., Jedi, S.(2014)Streptozotocin-NicotinamideInduced Rat Model of Type 2 diabetes (Review). Acta Physiol Hung, 101(4), 408-420,

doi:10.1556/APhysiol.101.2014.4.2

IACUC UIOWA.(2016).IACUC Guidelines: Anesthesia. Iowa: Office of Animal Resources | Institutional Animal Care and Use Committee

International Diabetes Federation.(2006).The Diabetes Atlas (3rd ed.). Brussels, Belgium: International Diabetes Federation

Laqif, A.(2015). Kajian Terapi Media Terkondisi Sel Punca Mesensimal (MTSPM) Selaput Amnion pada Kasus Kegagalan Ovarium Prematur (Penelitian pada Hewan Coba Tikus Sprague-Dawley). Disertasi: Fakultas Kedokteran Universitas Gadjah Mada 
McGonnell, I.M., Grigoriadis, A.E., Lam,

E.W.-F. Price, J.S., Sunters, A. (2012).

A Specific Role for Phosphoinositide 3kinase and AKT in Osteoblasts?.Front

Endocrinol,3(88), 1-8, doi:

10.3389/fendo.2012.00088

Sari, M.I.(2007).Reseptor Insulin. Bahan

Ajar: Fakultas Kedokteran, Universitas Sumatera Utara

Tatullo, M., Marrelli, M., Paduano, F.(2015).The Regenerative Medicine in Oral and Maxillofacial Surgery: The Most Important Innovations in the Clinical Application of Mesenchymal Stem Cells. Int J Med Sci,12(1), 72-77, doi:10.7150/ijms.10706

Toda, A., Okabe, M., Yoshida, T., Nikaido, T.(2007).The Potential of Amniotic Membrane/Amnion-Derived Cells for Regeneration of Various Tissues. $J$ Pharmacol Sci, 105, 215 - 228

Varghese, F., Bukhari, A.B.,Malhotra, R., De, A.(2014). IHC Profiler: An Open Source Plugin for the Quantitative Evaluation and Automated Scoring of Immunohistochemistry Images of Human Tissue Samples.PLoS ONE9(5), e96801, doi:10.1371/journal.pone.0096801 